\title{
IMPLEMENTASI STUDENT CENTERED LEARNING DALAM PRAKTIKUM FISIKA DASAR
}

\author{
Rudy Kustijono \\ Dosen Jurusan Fisika Unesa \\ rudyunesa@gmail.com
}

\begin{abstract}
Abstrak
Telah dilakukan penelitian untuk mengimplementasikan student centered learning dalam praktikum fisika dasar. Berdasarkan pengalaman di jurusan fisika Unesa selama ini, kendala yang dijumpai adalah masih banyak mahasiswa yang belum dapat mandiri dalam melaksanakan kegiatan praktikumnya karena lebih banyak menunggu penjelasan dari pembimbing dan kurang berinisiatif dalam menyelesaikan masalah praktikumnya. Student centered learning (SCL) merupakan strategi pembelajaran yang menempatkan mahasiswa sebagai subyek aktif dan mandiri yang bertanggung jawab sepenuhnya atas pembelajarannya. Memperhatikan karakteristik praktikum yang lebih mengarah pada pengembangan keterampilan ilmiah (hard skills dan soft skills) mahasiswa dalam mengidentifikasi gejala dan menyelesaikan masalah perlu dilakukan pendekatan pembelajaran yang inovatif yang dapat mengembangkan keterampilan ilmiah mahasiswa secara maksimal. Untuk mengatasi keadaan tersebut, telah diujicobakan suatu mekanisme implementasi SCL dalam praktikum fisika dasar yang diharapkan dapat mengoptimalkan keterampilan praktikum mahasiswa. Efektivitas mekanisme kegiatan praktikum dengan pendekatan SCL tersebut dilihat berdasarkan sejauhmana sasaran yang diinginkan tersebut tercapai. Hasil implementasi student centered learning dalam penelitian ini menunjukkan bahwa: 1) Atribut-atribut student centered learning yang dapat diintegrasikan ke dalam praktikum fisika dasar meliputi: kerja kelompok, diskusi, menulis, presentasi, dan pemecahan masalah. 2) Atribut-atribut softs skills mahasiswa yang bersesuaian dengan atribut-atribut student centered learning yang diintegrasikan ke dalam praktikum fisika dasar adalah: kerjasama merupakan penekanan dari kegiatan kerja kelompok, manajemen diri merupakan penekanan dari kegiatan diskusi, komunikasi tulis merupakan penekanan dari kegiatan menulis, komunikasi lisan merupakan penekanan dari kegiatan presentasi, berfikir kritis dan analitis merupakan penekanan dari pemecahan pemecahan masalah. 3) Mekanisme implementasi student centered learning dalam praktikum fisika dasar melalui kegiatan yang meliputi: pralaboratorium, praktikum, pelaporan, dan presentasi. Implementasi student centered learning dalam praktikum fisika dasar tersebut dapat mendukung keterampilan praktikum. Mekanisme implementasi SCL dalam praktikum fisika dasar tersebut cukup efektif dalam membekali keterampilan praktikum yang harus dimiliki mahasiswa. 4) Mekanisme implementasi student centered learning dalam praktikum fisika dasar tersebut cukup efisien digunakan, karena mahasiswa maupun pembimbing praktikum dapat menggunakan waktu dan peralatan praktikum yang tersedia dengan baik.
\end{abstract}

Kata kunci: student centered learning, hard skills, soft skills 


\section{Pendahuluan}

\subsection{Latar Belakang}

Mahasiswa harus mempunyai bekal tidak hanya kecakapan pengetahuan dan keterampilan saja (hard skills) tetapi harus mempunyai kecakapan lunak seperti mampu memecahkan masalah, selalu berfikir kritis, dapat bekerja sama, mempunyai kepekaan, berjiwa kepemimpinan, cermat dalam mengambil keputusan dll, yang dikenal dengan soft skills. Dengan bekal kecakapan yang berimbang antara hard skills dan soft skills, mahasiswa setelah lulus diharapkan mampu berperan maksimal baik dalam lingkup kerjanya maupun di masyarakat luas. Oleh karena itu perguruan tinggi harus mampu menyesuaikan diri dengan kebutuhan yang berkembang di masyarakat termasuk diantaranya adalah membekali hard skills dan soft skills yang berimbang dari para lulusan perguruan tinggi.

Di sisi yang lain kecakapan ilmiah yaitu kemampuan melakukan prosedur ilmiah dan kepemilikan sikap ilmiah dalam praktikum fisika dasar memerlukan kecakapan pengetahuan dan keterampilan (hard skills) yang memadai dan dilakukan melalui proses yang menuntut sikap ilmiah dari mahasiswa seperti berfikir kritis, memecahkan masalah, jujur, bekerja sama, terbuka dan lain-lain. Atribut-atribut yang dikembangkan dalam sikap ilmiah tersebut mempunyai kesamaan dengan atributatribut dari kecakapan lunak (soft skills) sehingga penerapannya dapat diperluas tidak hanya berlaku dalam bidang penelitian saja tetapi dapat berlaku pada keperluan yang lebih umum. Dalam praktikum fisika dasar, mahasiswa dilatih agar mempunyai kecakapan ilmiah yaitu mampu melakukan prosedur ilmiah (menganalisis problema, mengumpulkan informasi, menyusun hipotesis, merencanakan percobaan, menarik kesimpulan, dan mempresentasikan hasil percobaan) dan dilatih untuk bersikap ilmiah (berfikir kritis, memecahkan masalah, jujur, bekerja sama, terbuka dan lain-lain). Untuk menghasilkan kecakapan mahasiswa yang maksimal, diperlukan strategi pembelajaran yang tepat agar semua potensi yang dimiliki mahasiswa dapat berkembang maksimal pula. Untuk itu perlu dilakukan pendekatan pembelajaran yang inovatif yang dapat mengembangkan kecakapan ilmiah mahasiswa secara maksimal.

Dalam pendidikan fisika, kegiatan laboratorium/praktikum mutlak ada karena merupakan penunjang dalam menambah pemahaman konsep fisika. Di samping itu, mahasiswa dapat dilatih keterampilanketerampilan yang mendasari eksperimen seperti keterampilan menggunakan alatalat ukur, keterampilan memilih metode pengambilan data pengukuran yang tepat, keterampilan mengolah data pengukuran yang diperoleh dan sebagainya.

Tujuan praktikum ditetapkan yang terutama berdasarkan fungsi praktikum yaitu latihan, umpan balik, dan memperbaiki motivasi mahasiswa. Sebagai fungsi latihan, praktikum dapat dimanfaatkan untuk melatihkan tiga keterampilan secara yaitu (Utomo\&Rujkes, 1991 [1]):

a. keterampilan kognitif yang tinggi meliputi: memperdalam teori yang telah diperoleh agar lebih dimengerti, dan mengembangkan strategi kognitif,

b. keterampilan afektif meliputi: belajar merencanakan kegiatan secara mandiri, dan belajar bekerja sama,

c. keterampilan psikomotor meliputi: belajar memasang peralatan tertentu sehingga betul-betul berjalan dan belajar memakai peralatan/instrumen tertentu.

Kendala yang dijumpai adalah masih banyak diantara mahasiswa dalam praktikum tingkat dasar yang belum siap berpraktikum yaitu tidak memiliki kemampuan prasyarat sebelum melakukan praktikum. Dengan keadaan seperti itu berarti mahasiswa belum dapat mandiri dalam melaksanakan kegiatan praktikumnya dan kurang berinisiatif dalam menyelesaikan masalah praktikumnya. Dengan kondisi demikian maka mahasiswa sangat pasif dan kurang mengembangkan 
kemampuaannya dalam praktikum tersebut. Kondisi ini seperti sinyalemen yang ada yaitu sebagian besar pendidik, guru dan dosen hanya mengurusi aspek hard skill (kognitif dan psikomotorik). Masalah soft skill (afektif) terabaikan dan pendekatan pembelajaran yang digunakan jarang mendorong tumbuhnya soft skill (Made Tirta, 2009 [2]).

SCL merupakan strategi pembelajaran yang menempatkan mahasiswa sebagai peserta didik (subjek) aktif dan mandiri, dengan kondisi psikologik sebagai adult learner, bertanggung jawab sepenuhnya atas pembelajaran, serta mampu belajar beyond the classroom. Kelak, para alumni diharapkan memiliki dan menghayati karakteristik life-long learning yang menguasai hard skills dan soft skills yang saling mendukung. Di sisi lain, para dosen beralih fungsi, dari pengajar menjadi mitra pembelajaran maupun sebagai fasilitator (from mentor in the center to guide on the side) (Harsono, 2005[3]). Oleh karena itu, trend pembelajaran ke depan harus dapat melatihkan aspek hard skills dan soft skills secara terpadu. SCL memiliki potensi untuk mendorong mahasiswa belajar lebih aktif, mandiri, sesuai dengan irama belajarnya masing-masing, sesuai dengan perkembangan yang berjalan. Irama mahasiswa tersebut perlu dipandu agar terus dinamis dan mempunyai tingkat kompetensi yang tinggi (JTE FT UGM. 2004[4]).

Memperhatikan karakteristik praktikum yang lebih mengarah pada pengembangan keterampilan ilmiah (hard skills dan soft skills) mahasiswa dalam mengidentifikasi gejala dan menyelesaikan masalah fisika tentu tidak tepat jika pelaksanaan pembelajaran menggunakan strategi konvensional yang lebih mengarah pada teacher centered. Untuk itu perlu dilakukan pendekatan pembelajaran yang inovatif yang dapat mengembangkan keterampilan ilmiah mahasiswa secara maksimal melalui pendekatan SCL. Untuk mengatasi keadaan tersebut, diujicobakan suatu mekanisme implementasi SCL dalam praktikum fisika dasar yang diharapkan dapat mengoptimalkan keterampilan praktikum mahasiswa.

\subsection{Rumusan Masalah}

Dengan latar belakang di atas masalah yang dapat dirumuskan adalah: "Bagaimanakah mekanisme implementasi SCL dalam praktikum fisika dasar yang dapat mengoptimalkan keterampilan praktikum mahasiswa?". Pertanyaan penelitian yang dikemukakan:

a. Atribut-atribut SCL mana yang dapat mendukung berkembangnya keterampilan mahasiswa dalam melakukan praktikum fisika dasar?

b. Bagaimana integrasi atribut-atribut SCL tersebut dalam kegiatan praktikum fisika dasar?

c. Apakah mekanisme implementasi SCL dalam praktikum fisika dasar tersebut cukup efektif dalam membekali keterampilan praktikum yang harus dimiliki mahasiswa?

d. Apakah mekanisme implementasi SCL dalam praktikum fisika dasar tersebut cukup efisien digunakan, sehingga mahasiswa maupun pembimbing praktikum dapat menggunakan waktu dan peralatan praktikum yang tersedia?

\subsection{Tujuan Penelitian}

Tujuan utama penelitian adalah memperoleh mekanisme implementasi SCL dalam praktikum fisika dasar yang dapat mengoptimalkan keterampilan praktikum mahasiswa.

\subsection{Manfaat Penelitian}

Dari segi teoritis, manfaat yang diperoleh dari penelitian ini adalah dapat menemukan atribut-atribut SCL yang sesuai dengan kegiatan praktikum yang diharapkan dapat mendorong mahasiswa belajar dan bekerja secara mandiri. Dari segi praktis, mekanisme implementasi SCL dalam praktikum fisika dasar yang dapat mengoptimalkan keterampilan praktikum mahasiswa tersebut diharapkan dapat membantu meningkatkan kinerja mahasiswa, dosen, dan laboratorium fisika. 


\section{Tinjauan Pustaka}

\subsection{Kombinasi Hard Skills dan Soft Skills}

Sebagian besar perusahaan-perusahaan pengguna lulusan perguruan tinggi saat ini tidak hanya membutuhkan hard skills saja melainkan juga mental dan jiwa leadership calon lulusan. Perusahaan lebih menginginkan pekerja yang cakap tapi juga mampu bekerja sama dalam tim. Jika perguruan tinggi hanya mengembangkan aspek akademik saja tanpa diimbangi pemantapan kemampuan bekerja sama dalam tim, jiwa kepemimpinan serta kemampuan berkomunikasi yang baik dengan pihak lain, maka waktu tunggu pekerjaan alumni akan semakin lebar. Komposisi yang berimbang antara hard skills dan soft skills inilah nantinya yang akan membuat para alumni mampu memberikan kontribusi yang berarti terhadap lembaga pengguna lulusan.

\subsection{Atribut-atribut Hard Skills dan Soft Skills \\ Hard skills menggambarkan perilaku} dan keterampilan yang dapat dilihat mata (eksplisit). Hard skills adalah skills yang dapat menghasilkan sesuatu yang sifatnya visible dan immediate. Hard skills adalah semua hal yang berhubungan dengan pengayaan teori yang menjadi dasar pijakan analisis atau sebuah keputusan (Fachrunnisa, 2006 [5]), Hard skills tersebut didapat mahasiswa melalui mata kuliah yang diambil sesuai dengan fakultas dan jurusannya masing-masing. Hard skills dapat dinilai dari technical test atau practical test. Elemen-elemen (atribut-atribut) hard skills dapat terlihat dari intelligence quotient thinking (IQ) yang mempunyai indikator kemampuan menghitung, menganalisa, mendesain, wawasan dan pengetahuan yang luas, membuat model, dll (Santoso dkk, 2005[6]). Jadi hard skills adalah kecakapan teknis atau kecakapan praktis, seperti kecakapan bidang komputer, kecakapan bidang teknik, dan lain-lain.
Soft skills menurut Berthal: "Personal and interpersonal behaviors that develop and maximize human performance (e.g. coaching, team building, decision making, initiative). Soft skills do not include technical skills, such as financial, computer or assembly skills" (dikutip Made Tirta dan Illah Sailah, 2009[7]). Soft Skills didefinisikan sebagai perilaku personal dan interpersonal yang mengembangkan dan memaksimalkan kinerja humanis. Atribut-atribut soft skills sangat banyak ragamnya, misalnya NACE (National Association of College and Employee) USA menetapkan 20 atribut soft skills, sedangkan Patrick S. O'Brien dalam bukunya Making College Count, soft skill dapat dikategorikan ke dalam 7 area yang disebut Winning Characteristics. yaitu, communication skills, organizational skills, leadership, logic, effort, group skills, dan ethics. Kemampuan non teknis yang tidak terlihat wujudnya (intangible) namun sangat diperlukan itu, disebut soft skills (Dewi Irma, 2009[8]).

Banyak para ahli yang melakukan penelitian tentang atribut-atribut soft skills diantaranya Theresa Kane (2003)[9] yang menyatakan bahwa para pimpinan perusahaan menginginkan para pekerja mempunyai kecakapan-kecakapan seperti: kecakapan sosial, kecakapan menjalin hubungan antar pribadi, kesadaran diri, dan kecakapan pengendalian emosi.

Barbara Dwyer (2009)[10] memberikan gambaran 10 kecakapan utama yang dimiliki karyawan yang diminati oleh penyedia kerja yaitu:

a. Communications Skills.

b. Decision Making Skills.

c. Computer/Technical Skills.

d. Flexibility/Adaptability/Managing Multiple Priorities.

e. Interpersonal/Employee Relations Skills.

f. Leadership/Management Skills.

g. Multicultural Sensitivity/Awareness.

h. Planning/Organizing Skills.

$i$. Creativity Skills.

j. Teamwork Skills. 
Illah Sailah (2009)[7] dan Widji Soeratri (2009)[11] memberikan alternatif atributatribut soft skills yang memungkinkan dapat dipadukan dalam pembelajaran sebagai berikut:

a. Komitmen

b. Inisiatif

c. Kemampuan untuk belajar

d. Handal

e. Percaya diri

f. Kemampuan berkomunikasi

g. Antusias

h. Berani mengambil keputusan

i. Integritas

j. Motivasi untuk meraih prestasi/ Gigih

k. Berkreasi

1. Kerjasama dalam tim

m. Berfikir kritis

n. Menghargai (pendapat) orang lain

\subsection{Konsep Kecerdasan Individu}

Pembahasan tentang soft skills, secara teoretis tidak dapat dilepaskan dengan konsep kecerdasan. Untuk itu, kerangka berfikir tentang pengembangan soft skills yang berhubungan dengan student centered learning juga mengacu pada konsep kecerdasan tersebut.

Saat ini berkembang konsep kecerdasan majemuk atau lebih dikenal dengan multiple inteligence. Menurut pandangan multiple intelligence, Intelligene Quotien (IQ) bukan satu-satunya hal yang menentukan (penentu) keberhasilan seseorang. Howard Gamer seperti dikutip oleh Zainuddin dkk (2009)[12] memisahkan kecerdasan ke dalam tujuh ranah, yaitu:
a. logical mathematical intelligence
b. linguistic intelligence
c. musical intelligence
d. spatial intelligence
e. bodilyikinesthetic intelligence
$f$. interpersonal intelligence
g. intropersonal intelligence

Berdasarkan konsep tersebut, kemudian bermunculan berbagai teori kecerdasan yang berkembang akhir-akhir ini, seperti: kecerdasan emosi, kecerdasan menghadapi kesulitan, kecerdasan moral, kecerdasan spiritual, dan lain sebagainya. Tiga konsep yang digunakan digunakan sebagai dasar pengembangn soft skils yang berhubungan dengan student centered learning adalah kecerdasan emosional, kecerdasan menghadapi kesulitan, dan kecerdasan moral.

Goleman (1999)[13] yakin bahwa kecerdasan intelektual hanya menyumbangkan $20 \%$ bagi kesuksesan hidup individu, sedangkan selebihnya adalah sumbangan dari kecerdasan emosinya. Kecerdasan emosi atau Emotional Quotion (EQ) menggambarkan kemampuan seorang individu untuk mampu mengelola dorongan-dorongan dalam dirinya terutama dorongan emosinya. Kecerdasan emosi menurut Goleman sangat penting karena mempengaruhi prestasi, mempengaruhi keterampilan perilaku, dan mempengaruhi penyesuaian sosial. Sementara itu kecerdasan intelektual hanya mengacu pada kemampuan belajar yang dicapai oleh individu.

Stolz (1997)[14] menyebutkan bahwa selain kecerdasan emosi yang dapat mendukung pencapaian kesuksesan, individu perlu mengembangkan kecerdasan menghadapi kesulitan dan tantangan. Kecerdasan menghadapi kesulitan diperkenalkan oleh Stoltz sebagai Adversity Quotien (AQ), yaitu tingkat kecerdasan seseorang untuk tetap bertahan hidup. Seseorang yang memiliki tingkat AQ tinggi akan tetap bersemangat menghadapi dan menjalani kehidupan ini, sekalipun berbagai rintangan dan hambatan harus dilalui.

Borba (2001)[15] menyatakan bahwa kecerdasan moral ialah kapasitas individu untuk memahami dan membedakan nilai yang salah atau benar, baik atau buruk. Hal ini menunjukkan individu terebut mempunyai pendirian etis yang kuat sehingga mampu bertindak dalam perilaku yang benar. Berdasarkan pengertian tersebut, Borba menegaskan bahwa kecerdasan moral ini dapat dikembangkan dengan pendidikan dan penanaman nilai moral. 


\subsection{Hard Skills dan Soft Skills Yang Terpadu Dengan Matakuliah}

Perguruan tinggi perlu merespon melalui kurikulum, metode pengajaran, media pengajaran dan hal-hal lain yang dapat digunakan untuk menciptakan link and match antara perguruan tinggi dan dunia kerja.

Implikasi kondisi tersebut adalah dibutuhkan pendekatan baru dalam pembelajaran yang mengintegrasikan hard skills dan soft skills. Selanjutnya langkahlangkah yang dapat dilakukan adalah:

a. Perguruan Tinggi membuat soft skills statement dari lulusan yang diintegrasikan dengan kompetensi lulusan, yang akan menjadi brand image lulusan.

b. Perguruan Tinggi mengidentifikasi kemampuan soft skills yang akan dikembangkan oleh mahasiswa baru

c. Perguruan Tinggi membuat perencanaan untuk masing-masing tingkat, sehingga tergambarkan proses pembangunan karakter yang dikehendaki sampai mahasiswa lulus

d. Perguruan Tinggi membuat program terobosan yang khas dengan mempertimbangkan sumberdaya yang ada dalam pengembangan soft skills.

\subsection{Student Centered Learning (SCL) dalam Praktikum Fisika Dasar}

Pembuatan prosedur instruksi yang sesuai dalam praktikum sehingga keterampilan yang diinginkan dapat dilatihkan kepada mahasiswa dan benar-benar mencapai tujuan memerlukan metode praktikum yang tepat. Urutan langkah praktikum secara umum adalah: menganalisis problema, mengumpulkan informasi, menyusun hipotesis, merencanakan percobaan, dan menarik kesimpulan.

Pelaksanaan praktikum memerlukan organisasi yang baik dan cara bimbingan yang tepat sehingga siswa dapat belajar dari kesalahannya.

Di FMIPA Unesa, mata kuliah Fisika Dasar adalah salah satu mata kuliah TPB (Tahun Pertama Bersama) yang harus diprogram oleh mahasiswa dari semua jurusan yang ada di FMIPA yaitu Fisika, Matematika, Kimia, dan Biologi. Isi praktikumnya adalah pengenalan berbagai alat ukur dan melatih cara menggunakannya, mengenalkan dasar-dasar eksperimentasi dan melatih menggunakannya dalam praktikum, serta mengembangkan strategi kognitif yang menunjang pemahaman mata kuliah Fisika Dasar.

SCL adalah sebuah proses belajar yang mengoptimalkan kemandirian mahasiswa sebagai manusia dewasa (andragogy) dengan menyeimbangkan kemampuan kognisi dan emosi.

Pembelajaran yang inovatif dengan pendekatan yang berpusat pada siswa memiliki keragaman model pembelajaran yang menuntut partisipasi aktif dari siswa yaitu (Tina Afiatin, 2009)[16]:

a. Berbagi Informasi (information sharing) dengan cara: curah pendapat (brainstorming), kooperatif, kolaboratif, diskusi kelompok (group discussion), diskusi panel (panel discussion), simposium, dan seminar.

b. Belajar dari pengalaman (experience based) dengan cara: simulasi, bermain peran (role-play).

c. Pembelajaran melalui pemecahan masalah (problem solving based) dengan cara: studi kasus, tutorial, dan lokakarya.

\subsection{Kerangka Konseptual}

SCL adalah sebuah proses belajar yang menyeimbangkan kemampuan kognisi, motorik, dan emosi. Oleh karena itu prinsip-prinsip utama dari SCL adalah:

a. Tanggung jawab, yaitu siswa mempunyai tanggung jawab pada pelajarannya..

b. Peranserta, yaitu siswa harus berperan aktif dalam pembelajaran.

c. Keadilan, yaitu semua siswa mempunyai hak yang sama untuk tumbuh dan berkembang.

d. Mandiri, yaitu semua siswa harus mengembangkan segala kecerdasannya (intelektual, emosi, moral, dsb). 
e. Berfikir kritis dan kreatif, yaitu siswa harus menggunakan segala kecerdasan intelektual dan emosinya yang berwujud kreativitas, inovasi, dan analisis.

f. Komunikatif, yaitu siswa harus menggunakan kemampuannya berkomunikasi baik lisan maupun tertulis.

g. Kerjasama, yaitu kondisi dimana para siswa dapat saling bersinergi dan saling mendukung pencapaian keberhasilan atau tujuan yang ditetapkan dalam pembelajaran.

h. Integritas, yaitu siswa harus menunjukkan perilaku moralitas tinggi, dan percaya diri dalam melaksanakan segala sesuatu yang diyakininya dalam situasi apapun.
Dengan prinsip-prinsip seperti diuraikan di atas dapat diketahui bahwa hampir semua atribut-atribut soft skills dapat mendukung penerapan student centered learning. Namun demikian tidak semua atribut soft skills dapat dilatihkan atau diintegrasikan dalam setiap mata pelajaran. Perlu dipilah dan dipilih atribut mana yang paling memungkinkan untuk diterapkan dalam suatu matakuliah atau setidaknya ada penekanan pada beberapa atribut. Dalam penelitian ini ditetapkan beberapa atribut soft skills yang dikemas menjadi atribut student centered learning seperti tabel 1.

Tabel 1. Atribut-atribut soft skills dalam student centered learning

\begin{tabular}{|c|l|l|l|}
\hline No. & \multicolumn{1}{|c|}{ Atribut SCL } & \multicolumn{1}{c|}{ Atribut Soft Skills } & \multicolumn{1}{c|}{ Penekanan } \\
\hline 1. & Kerja kelompok & $\begin{array}{l}\text { Penyesuaian diri, hubungan sosial, komunikasi lisan, kerja sama, } \\
\text { motivasi berprestasi, orientasi belajar, manajemen diri, etika, etos } \\
\text { kerja, berfikir kritis dan analitis, integritas, manajemen waktu, } \\
\text { organisasi, kepemimpinan. }\end{array}$ & Kerja sama \\
\hline 2. & Diskusi & $\begin{array}{l}\text { Kepercayaan diri, penyesuaian diri, hubungan sosial, komunikasi lisan, } \\
\text { kerja sama, motivasi berprestasi, orientasi belajar, manajemen diri, } \\
\text { etika, etos kerja, berfikir kritis dan analitis, integritas, manajemen } \\
\text { waktu, ketangguhan diri, organisasi, kepemimpinan }\end{array}$ & Manajemen diri \\
\hline 3. & Menulis & $\begin{array}{l}\text { Kepercayaan diri, komunikasi tulis, motivasi berprestasi, orientasi } \\
\text { belajar, manajemen diri, etika, etos kerja, berfikir kritis dan analitis, } \\
\text { integritas, manajemen waktu, ketangguhan diri. }\end{array}$ & Komunikasi tulis \\
\hline 4. & Presentasi & $\begin{array}{l}\text { Kepercayaan diri, penyesuaian diri, komunikasi lisan, motivasi } \\
\text { berprestasi, orientasi belajar, manajemen diri, etika, etos kerja, berfikir } \\
\text { kritis dan analitis, integritas, manajemen waktu, ketangguhan diri. }\end{array}$ & Komunikasi lisan \\
\hline 5. & $\begin{array}{l}\text { Pemecahan } \\
\text { Masalah }\end{array}$ & $\begin{array}{l}\text { Kepercayaan diri, penyesuaian diri, motivasi berprestasi, orientasi } \\
\text { belajar, manajemen diri, etika, etos kerja, berfikir kritis dan analitis, } \\
\text { integritas, ketangguhan diri. }\end{array}$ & $\begin{array}{l}\text { Berfikir kritis dan } \\
\text { analitis }\end{array}$ \\
\hline
\end{tabular}

Atribut-atribut dalam studentcentered learning yang dapat diintegrasikan ke dalam praktikum antara lain:

\section{a. Kerja Kelompok}

Interaksi sosial yang positif dapat dibentuk melalui kerja berkelompok. Perasaan senasib sepenanggungan antara sesama teman dalam kelompok dan keunggulan dari belajar dalam peer dan cohort (teman seangkatan) adalah faktor positif yang akan dimanfaatkan.

\section{b. Diskusi}

Mahasiswa akan lebih mudah untuk menyerap dan memahami suatu hal atau fenomena yang dijelaskan oleh temannya dengan gaya bahasa dan pendekatan komunikasi dari mahasiswa lain pada usianya.

\section{c. Menulis}

Hasil tulisan baik berupa laporan, ulasan, sampai bentuk tulisan karya ilmiah merupakan refleksi capaian kemampuan dan pemahaman pada diri mahasiswa. 


\section{d. Presentasi}

Dalam proses pembelajaran, presentasi yang baik sangat menunjang penyampaian informasi pengetahuan, baik dari sisi kecepatan maupun bobotnya.

e. Pemecahan Masalah

Semua atribut SCL tersebut bermuara pada pemecahan masalah. Unsur dasar dari pemecahan masalah adalah proses berfikir kritis (critical thingking).

Atribut-atribut dalam SCL tersebut selanjutnya diintegrasikan dalam kegiatan praktikum yang meliputi kegiatan pralaboratorium, kegiatan praktikum, pelaporan, dan presentasi yang terinci seperti tabel 2 berikut:

Tabel 2. Integrasi atribut-atribut SCL dalam praktikum fisika dasar

\begin{tabular}{|c|l|l|l|}
\hline No. & \multicolumn{1}{|c|}{ Atribut SCL } & $\begin{array}{l}\text { Mekanisme kegiatan dalam praktikum } \\
\text { fiska dasar }\end{array}$ & \multicolumn{1}{c|}{$\begin{array}{c}\text { Sasaran yang diharapkan pada } \\
\text { mahasiswa }\end{array}$} \\
\hline 1. & Kerja kelompok & $\begin{array}{l}\text { tugas kelompok untuk mempersiapkan } \\
\text { alat dan bahan yang diperlukan dalam } \\
\text { praktikum dan mempelajari panduan } \\
\text { praktikum yang selanjutnya } \\
\text { melaksanakan kegiatan praktikumnya }\end{array}$ & $\begin{array}{l}\text { Mampu mempersiapkan alat dan bahan, } \\
\text { mampu mengidentifikasi variabel } \\
\text { percobaan, mampu melaksanakan } \\
\text { praktikum, menghasilkan kinerja tim yang } \\
\text { baik }\end{array}$ \\
\hline 2. & Diskusi & kegiatan pralaboratorium & $\begin{array}{l}\text { Mampu berkolaborasi dalam } \\
\text { menyelesaikan masalah praktikum }\end{array}$ \\
\hline 3. & Menulis & $\begin{array}{l}\text { menulis laporan praktikum fisika dasar } \\
\text { yang berupa artikel ilmiah }\end{array}$ & $\begin{array}{l}\text { Mampu membuat laporan praktikum berupa } \\
\text { artikel yang memenuhi kaidah ilmiah }\end{array}$ \\
\hline 5. & Pemecahan masalah & $\begin{array}{l}\text { kegiatan seminar laporan praktikum dari } \\
\text { tiap-tiap topik }\end{array}$ & $\begin{array}{l}\text { Mampu mengkomunikasikan gagasan } \\
\text { dengan penampilan dan teknologi } \\
\text { pendukung yang baik }\end{array}$ \\
\hline & & satu topik praktikum fisika dasar. & $\begin{array}{l}\text { Mampu memperoleh data percobaan suatu } \\
\text { topik praktikum fisika dasar dan } \\
\text { menganalisisnya dengan baik }\end{array}$ \\
\hline
\end{tabular}

Student centered learning dalam praktikum fisika dasar dilaksanakan melalui mekanisme memadukan atributatribut soft skills yang sesuai dengan student centered learning ke dalam kompetensi yang ditetapkan pada kegiatan praktikum fisika dasar. Dengan memadukan atribut-atribut tersebut, proses pembelajaran dalam praktikum diharapkan dapat mengoptimalkan kemandirian mahasiswa dengan kompetensi yang menyeimbangkan kecerdasan intelektual, kecerdasan motorik, dan kecerdasan emosi. Proses perkembangan kompetensi tersebut selanjutnya diamati dan dinilai melalui tahapan praktikum yang meliputi kegiatan pralaboratorium, kegiatan praktikum, pelaporan, dan presentasi.

Kegiatan pralaboratorium adalah proses pembelajaran yang melatih mahasiswa agar siap melakukan kegiatan praktikum secara terencana dan sistematis.
Kegiatan praktikum adalah proses pembelajaran yang melatih mahasiswa agar dapat melakukan kegiatan praktikum secara terencana dan sistematis. Kegiatan praktikum ini lebih menitik beratkan pada proses ilmiah dan penguasaan penggunaan alat ukur di samping penguasaan materi fisika.

Kegiatan pelaporan adalah satu proses pembelajaran yang melatih mahasiswa agar dapat melaporkan kegiatan praktikum secara tertulis dengan baik, ilmiah, dan bertanggung jawab. Pelaporan tersebut diharapkan dapat mencerminkan penguasaan mahasiswa tentang penguasaan praktikum (prosedur, data, analisis, kesimpulan, dll) dan penguasaan materi fisika.

Kegiatan presentasi adalah proses pembelajaran yang melatih mahasiswa agar dapat melaporkan kegiatan praktikum 
secara lisan dan tulis yang terpadu dengan baik, ilmiah, dan bertanggung jawab.

\subsection{Hipotesis Tindakan}

Berdasarkan kerangka berfikir seperti diuraikan di atas, hipotesis tindakan dapat dikemukakan sebagai berikut: "Penerapan atribut-atribut SCL yang meliputi kerja kelompok, diskusi, menulis, presentasi, dan peme-cahan masalah dapat mengoptimalkan keterampilan mahasiswa dalam melakukan praktikum fisika dasar".

\section{Metode Penelitian}

\subsection{Bentuk Penelitian}

Penelitian ini adalah penelitian tindakan kelas (classroom action research), yaitu penelitian yang dilakukan untuk mencari suatu dasar pengetahuan praktis dalam rangka memperbaiki keadaan atau suatu situasi yang dilakukan secara terbatas, hal ini dilakukan terhadap suatu situasi atau keadaan yang sedang berlangsung (Ali, 1994)[17]. Penelitian tindakan adalah suatu penelitian yang dilakukan mengenai apa yang dilaksanakan tanpa mengubah sistem pelaksanaannya, meneliti sambil terus memperbaiki pelaksanaannya (Suharsimi, 1992)[18]. Tujuan penelitian tindakan tersebut adalah untuk mengembangkan keterampilan baru atau cara pendekatan baru untuk memecahkan masalah dengan penerapan langsung di dunia aktual (Suryabrata, 1989)[19].

\subsection{Sasaran Penelitian}

Sasaran penelitian adalah pelaksanaan praktikum fisika dasar yang menggunakan pendekatan SCL yang dilaksanakan dengan subyek penelitian mahasiswa pendidikan fisika yang memprogram matakuliah fisika dasar.

\subsection{Langkah Penelitian}

Langkah-langkah yang dilakukan adalah sebagai be-rikut:

\section{Siklus pertama:}

Tahap 1 (tahap persiapan) :

a. Mengidentifikasi standar kompetensi pada matakuliah fisika dasar se- lanjutnya mengidentifikasi karakteristik praktikum tersebut.

b. Menetapkan atribut-atribut SCL yang dapat dipadukan dalam praktikum fisika dasar.

c. Menetapkan topik praktikum fisika dasar yang perlu mendapatkan penekanan dalam penerapan SCL.

d. Membuat instrumen yang diperlukan untuk mengetahui efektivitas mekanisme kegiatan praktikum tersebut dalam mengoptimalkan keterampilan praktikum mahasiswa

Tahap 2(tahap penerapan dan obser-vasi):

e. Menerapkan mekanisme kegiatan praktikum yang telah direncanakan dan mengobservasi pelaksanaannya dengan menggunakan instrumen yang telah dibuat sehingga diperoleh data-data yang dapat dipakai untuk mengetahui efektivitas mekanisme kegiatan praktikum fisika dasar tersebut

Tahap 3 (tahap refleksi) :

f. Merefleksikan data-data yang telah diperoleh dengan mengeksplorasi, menginterpretasi, menganalisis, dan mensintesis

g. Dari refleksi yang dilakukan dapat diketahui kelebihan dan kelemahan dari pelaksanaan kegiatan praktikum, selanjutnya disimpulkan apakah mekanisme kegiatan tersebut cukup efektif dan efisien. Dari refleksi tersebut selanjutnya dilakukan perbaikan sebagai dasar pelaksanaan berikutnya.

Siklus berikutnya : melaksanakan tahapan seperti siklus sebelumnya dengan memperhatikan perbaikan. Selanjutnya disimpulkan optimalisasi mekanisme implementasi SCL dalam praktikum fisika dasar.

\subsection{Instrumen Penelitian}

Instrumen penelitian yang digunakan untuk mengumpulkan data dalam penelitian ini meliputi:

\section{Lembar Pengamatan Proses Kegiatan}

Lembar pengamatan proses kegiatan digunakan untuk mengamati aktifitas 
dosen dan aktifitas mahasiswa dalam kegiatan praktikum fisika dasar.

\section{Angket Mahasiswa}

Angket ini ditujukan kepada mahasiswa, disusun dengan tujuan untuk memperoleh tanggapan mahasiswa mengenai berbagai hal yang berkaitan dengan proses kegiatan praktikum yang telah berlangsung.

\subsection{Jenis dan Analisis Data}

Data yang diperoleh adalah data kuantitatif dan data deskriptif. Analisis data yang digunakan dalam penelitian ini adalah statistik deskriptif. Data yang bersifat kuantitatif diolah dengan stastistik yang sesuai.

\section{Hasil dan Pembahasan}

\subsection{Implementasi SCL pada Praktikum a. Hasil implementasi pada siklus 1:}

Hasil implementasi kegiatan pralaboratorium pada siklus 1 menunjukkan bahwa secara umum soft skills mahasiswa yang mendukung SCL yang meliputi: kepercayaan diri, komunikasi lisan, kerjasama, berfikir kritis dan analitis, dan manajemen diri belum memuaskan karena masih lebih dari $15 \%$ mahasiswa berada pada level 2 (kurang) dan yang perlu perhatian lebih adalah kemampuan mahasiswa untuk berfifir kritis dan analitis karena sekitar 50\% mahasiswa berada pada level 2.

Hasil implementasi kegiatan praktikum pada siklus 1 menunjukkan bahwa secara umum soft skills mahasiswa yang mendukung SCL yang meliputi: kerjasama, etos kerja, manajemen waktu, inovasi, dan estetika belum memuaskan karena lebih dari $15 \%$ mahasiswa berada pada level 2 (kurang) dan yang perlu perhatian lebih adalah kemampuan berinovasi dan berestetika karena sekitar $50 \%$ mahasiswa berada pada level 2 (kurang). Sebagian mahasiswa tidak mampu menghasilkan gagasan atau karya baru berdasarkan potensi diri dan kurang mempunyai perilaku yang mengarah kepada keindahan, kebersihan, dan keserasian.

Hasil implementasi kegiatan pelaporan siklus 1 menunjukkan bahwa secara umum soft skills mahasiswa yang mendukung SCL yang meliputi: berfikir kritis dan analitis, komunikasi tulis, dan estetika belum memuaskan karena masih lebih dari $15 \%$ mahasiswa berada pada level 2 (kurang) terutama pada kemampuan berfikir kritis dan analitis yang mencapai lebih $25 \%$ mahasiswa berada pada level 2 (rendah). Sebagian mahasiswa belum mampu menemukan inti permasalahan dan alternatif penyelesaian dengan alur berfikir logis, hanya sekitar $14 \%$ saja mahasiswa yang mampu berfikir kritis dan analitis. Tapi kalau dibandingkan dengan mahasiswa ketika melaksanakan kegiatan pralaboratorium yang mencapai $50 \%$ mahasiswa yang berfikir kritis dan analitisnya berada pada level 2 (rendah), hasil tersebut sudah menunjukkan peningkatan berarti.

Hasil implementasi kegiatan presentasi pada siklus 1 menunjukkan bahwa secara umum soft skills mahasiswa yang mendukung SCL untuk kegiatan pelaporan yang meliputi: komunikasi tulis dan lisan, kepercayaan diri, manajemen waktu, kerjasama, berfikir kritis dan analitis, dan manajemen diri belum memuaskan karena masih lebih dari $15 \%$ mahasiswa berada pada level 2 (kurang), terutama kerjasama yang mencapai lebih 25\% mahasiswa masih berada dalam level 2 (kurang), kecuali menajemen diri dari mahasiswa yang berada pada level minimal cukup. Sebagian mahasiswa belum mempunyai kemampuan bekerja dan menyelesaikan pekerjaan bersama orang lain, tetapi sebagian yang lain sudah mempunyai kemampuan untuk mengelola potensi diri dan berusaha tampil dengan baik dalam presentasi.

Lemahnya kecakapan lunak (soft skills) mahasiswa pendukung SCL pada siklus 1 dapat dimaklumi karena mahasiswa dalam subyek penelitian ini adalah 
mahasiswa baru yang mungkin belum terbiasa dengan kerja kelompok yang membutuhkan kepercayaan diri, kemampuan berkomunikasi lisan, kemampuan bekerjasama, kemampuan berfikir kritis dan analitis, dan kemampuan manajemen diri. Di samping itu untuk kinerja yang baik juga memerlukan etos kerja yang baik, kemampuan manajemen waktu, kemampuan berinovasi dan estetika. Untuk memperbaiki kinerja mahasiswa dalam kegiatan praktikum (pralaboratorium, praktikum, pelaporan, dan presentasi) tersebut diperlukan pemahaman yang mendalam tentang kecakapan lunak (soft skills) untuk itu penjelasan kepada mahasiswa sebelum kegiatan dimulai diharapkan dapat mendorong mahasiswa memperbaiki kinerjanya. Untuk itu sebelum kegiatan dilaksanakan pada siklus 2, mahasiswa akan dibekali pemahaman tentang pentingnya berbagai kecakapan lunak (soft skills) yang mendukung SCL dan mendukung keberhasilan kegiatan praktikum pada umumnya. Langkah tersebut diharapkan dapat mendorong mahasiswa mempunyai soft skills dengan level 3 (cukup) ke atas atau dengan kata lain tidak ada lagi mahasiswa yang mempunyai soft skills dengan level kurang.

\section{b. Hasil implementasi pada siklus 2:}

Sebelum siklus 2 dilaksanakan, mahasiswa dibekali pemahaman tentang pentingnya berbagai kecakapan lunak (soft skills) yang mendukung SCL dan mendukung keberhasilan kegiatan praktikum pada umumnya.

Hasil implementasi kegiatan pralaboratorium pada siklus 2 menunjukkan bahwa secara umum soft skills mahasiswa yang mendukung SCL yang meliputi: kepercayaan diri, komunikasi lisan, kerjasama, berfikir kritis dan analitis, dan manajemen diri menunjukkan peningkatan yang berarti dibandingkan hasil implementasi pada siklus 1. Semua mahasiswa telah mempunyai kepercayaan diri, kemampuan komunikasi lisan, kerjasama, kemampuan berfikir kritis dan analitis, dan manajemen diri yang berada pada level minimal cukup atau tidak ada yang berada pada level kurang. Di samping itu terdapat sekitar $17 \%$ mahasiswa yang mempunyai kemampuan kerjasama, berfikir kritis dan analitis, dan manajemen diri pada level 5 (sangat baik).

Hasil implementasi kegiatan praktikum pada siklus 2 menunjukkan bahwa secara umum soft skills mahasiswa yang mendukung SCL yang meliputi: kerjasama, etos kerja, manajemen waktu, inovasi, dan estetika telah menunjukkan peningkatan yang berarti dibandingkan pada siklus 1. Semua mahasiswa mempunyai kemampuan kerjasama, etos kerja, manajemen waktu, inovasi, dan estetika yang berada berada pada level minimal cukup atau tidak ada mahasiswa yang mempunyai level kurang. Di samping itu terdapat sekitar 17\% mahasiswa yang mempunyai kemampuan kerjasama pada level 5 (sangat baik). Namun masih terdapat sekitar $17 \%$ mahasiswa yang mempunyai kemampuan berinovasi pada level 2 (kurang).

Hasil implementasi kegiatan pelaporan siklus 2 menunjukkan bahwa secara umum soft skills mahasiswa yang mendukung SCL yang meliputi: berfikir kritis dan analitis, komunikasi tulis, dan estetika menunjukkan peningkatan yang berarti. Semua mahasiswa telah mepunyai kemampuan berfikir kritis dan analitis, komunikasi tulis, dan estetika yang berada minimal pada level cukup, bahkan pada kemampuan berfikir kritis dan analitis serta kemampuan tulis terdapat $17 \%$ mahasiswa yang berada pada level 5 (sangat baik). Hasil pengamatan menunjukkan bahwa sebagian mahasiswa telah mampu menemukan inti permasalahan dan alternatif penyelesaian dengan alur berfikir logis, serta mempunyai kemampuan menyampaikan pendapat dan gagasan secara tertulis.

Hasil implementasi kegiatan presentasi pada siklus 2 menunjukkan bahwa secara umum soft skills mahasiswa yang mendukung $S C L$ untuk kegiatan pelaporan 
yang meliputi: komunikasi tulis dan lisan, kepercayaan diri, manajemen waktu, kerjasama, berfikir kritis dan analitis, dan manajemen diri telah menunjukkan peningkatan yang berarti dibandingkan dengan siklus 1. Semua mahasiswa telah mempunyai kemampuan komunikasi tulis dan lisan, kepercayaan diri, manajemen waktu, kerjasama, berfikir kritis dan analitis, dan manajemen diri yang berada pada level minimal cukup, bahkan kemampuan komunikasi tulis dan lisan, kemampuan berfikir kritis dan analitis terdapat $17 \%$ mahasiswa yang berada pada level 5 (sangat baik).

\subsection{Pengaruh SCL pada Praktikm}

Implementasi SCL dalam praktikum fisika dasar dengan mengintegrasikan atribut soft skills yang bertitik berat pada kemampuan kerjasama, kemampuan komunikasi tulis dan lisan, kemampuan berfikir kritis dan analitis, dan manajemen diri, telah memberikan sumbangan yang berarti pada kemampuan berpraktikum mahasiswa secara umum. Nilai rata-rata praktikum fisika dasar dari mahasiswa pada siklus 1 dan siklus 2 adalah seperti tabel 3:

Tabel 3. Nilai rerata praktikum

\begin{tabular}{|c|c|c|}
\hline & $\mathrm{X}_{\text {rerata }}$ & $\sigma_{\mathrm{x}}$ \\
\hline Siklus 1 & 71,1 & 0,6 \\
\hline Siklus 2 & 77,3 & 2,6 \\
\hline
\end{tabular}

Hasil penilaian menunjukkan bahwa lemahnya soft skills pada siklus 1 berdampak pada nilai praktikum pada siklus 1 dan peningkatan soft skills mahasiswa pada siklus 2 juga berdampak pada peningkatan nilai praktikum mahasiswa pada siklus 2. Tapi kalau dibandingkan standar deviasi dari masingmasing siklus, standar deviasi pada siklus 1 lebih kecil dibandingkan dengan standar deviasi pada siklus 2 yang berarti varian nilai mahasiswa pada siklus 2 juga lebih besar. Ini menunjukkan bahwa kemampuan mahasiswa pada siklus 2 lebih beragam. Hal penting yang ditekankan adalah tidak ada seorangpun mahasiswa yang mempunyai soft skills (kerjasama, komunikasi tulis dan lisan, berfikir kritis dan analitis, dan manajemen diri) yang mendukung SCL tersebut yang berada pada level dibawah 3. Dengan mengimplementasikan kegiatan tersebut secara berkala, diharapkan dapat mendorong mahasiswa meningkatkan kemampuannya baik hard skills maupun soft skills.

Berdasarkan hasil yang diperoleh dari siklus 1 dan siklus 2, masih didapatkan sebagian mahasiswa yang mempunyai kemampuan inovasi kurang yaitu belum mampu menghasilkan gagasan atau karya baru berdasarkan potensi diri. Namun demikan, dengan implementasi SCL dalam praktikum fisika dasar secara berkala diharapkan akan meningkatkan kemampuan mahasiswa dalam berinovasi tersebut. Di samping itu dengan penerapan yang berkala tersebut akan berkembang pula kemampuan-kemampuan yang lain seperti: kepercayaan diri, etos kerja, manajemen waktu, estetika dll.

Implementasi SCL dalam praktikum fisika dasar dengan mengintegrasikan atribut soft skills yang bertitik berat pada kemampuan kerjasama, kemampuan komunikasi tulis dan lisan, kemampuan berfikir kritis dan analitis, dan manajemen diri, dapat dilaksanakan dengan baik oleh dosen pembimbing dan asisten praktikum fisika dasar tanpa kendala yang berarti. Ditinjau dari pelaksanaan kegiatan praktikum secara keseluruhan sangat menunjang efektivitas dan efisiensi karena implementasi SCL tersebut mendorong dosen dan mahasiswa melaksanakan tugasnya secara maksimal, yaitu dapat menggunakan waktu dan peralatan praktikum yang tersedia dengan secara maksimal.

Berdasarkan dampak positip yang diperoleh dari implementasi SCL dalam praktikum fisika dasar tersebut, keberlajutan program dan tindak lanjutnya menjadi sangat penting untuk dipikirkan. 


\section{Kesimpulan dan Saran}

\subsection{Kesimpulan}

Berdasarkan hasil dan pembahasan yang telah diuraikan di atas, dapat disimpulkan berbagai hal sebagai berikut:

a. Atribut-atribut SCL yang dapat diintegrasikan ke dalam praktikum fisika dasar meliputi: kerja kelompok, diskusi, menulis, presentasi, dan pemecahan masalah.

b. Atribut-atribut softs skills mahasiswa yang bersesuaian dengan atributatribut SCL yang diintegrasikan ke dalam praktikum fisika dasar adalah: kerjasama merupakan penekanan dari kegiatan kerja kelompok, manajemen diri merupakan penekanan dari kegiatan diskusi, komunikasi tulis merupakan penekanan dari kegiatan menulis, komunikasi lisan merupakan penekanan dari kegiatan presentasi, berfikir kritis dan analitis merupakan penekanan dari pemecahan pemecahan masalah.

c. Mekanisme implementasi SCL dalam praktikum fisika dasar melalui kegiatan yang meliputi: pralaboratorium, praktikum, pelaporan, dan presentasi. Implementasi SCL dalam praktikum fisika dasar tersebut dapat mendukung keterampilan praktikum karena lemah atau kuatnya atribut soft skills pendukung SCL berdampak pada nilai praktikum. Jadi mekanisme implementasi SCL dalam praktikum fisika dasar tersebut cukup efektif dalam membekali keterampilan praktikum yang harus dimiliki mahasiswa.

d. Mekanisme implementasi SCL dalam praktikum fisika dasar tersebut cukup efisien digunakan, karena mahasiswa maupun pembimbing praktikum dapat menggunakan waktu dan peralatan praktikum yang tersedia dengan baik.

\subsection{Saran}

Berdasarkan dampak positip yang diperoleh dari implementasi student centered learning dalam praktikum fisika dasar, keberlajutan program dan tindak lanjutnya menjadi sangat penting untuk dipikirkan. Oleh karena itu implementasi student centered learning dalam praktikum fisika dasar dapat direkomendasikan untuk dilaksanakan di semua kegiatan praktium fisika dasar di Jurusan Fisika Unesa.

\section{Daftar Pustaka}

[1] Utomo, Rujkes, 1991, Peningkatan dan pengembangan Pendidikan, Jakarta: Gramedia.

[2] Made Tirta, 2009, Pembelajaran Terintegrasi. Tersedia pada http://www. Muhlis.file.wordpres.com.

[3] Harsono, 2005, Kearifan dalam transformasi pembelajaran: dari teacher-centered ke student-centered learning. Tersedia pada http://www. inparametric.com.

[4] Student Centered Learning Berbsis ICT, JTE FT UGM. Tersedia pada http://www. icts-sc.pbwiki.com.

[5] Fachrunnisa, Olivia. 2006. Pendidikan Berbasis Soft Skill Pada Perguruan Tinggi Manajemen Unt Meningkatkan Kualitas Profesional Manajemen. Prosiding Konferensi Merefleksi Domain Pendidikan Ekonomi Dan Bisnis. FE-UKSW: Salatiga.

[6] Santoso, Bedjo dan Fachrunnisa, 2005, Model Penerapan Soft Skill Di Perguruan Tinggi.

[7] Illah Sailah, 2009, Pengembangan Soft Skills Di Perguruan Tinggi, P2SDM LPPM IPB

[8] Dewi Irma, 2009, Lulusan PT butuh Soft Skills. Tersedia pada http://www. fe.elcom.umy.ac.id.

[9] Theresa. Kane, 2005, Soft skills are hard - and critical to career success Tersedia pada http://www. akacademy.com. 
[10] Barbara Dwyer, No Soft Skills No Jobs. Tersedia pada http://www. thejobjourney.org.

[11]Widji Soeratri, Implementasi Soft skills dalam pembelajaran. Tersedia pada http://www. perbanas.ac.id.

[12] Zainuddin. dkk, 2009, Melejitkan Soft Skills Mahasiswa, Surabaya: Airlangga University Press.

[13] Goleman, 1999, Working with Emotional Question. Jakarta: PT Gramedia Pustaka Utama.

[14] Stoltz, 1977, Adversity Quotien, Jakarta: PT Grasindo
[15] Borba, Michele, 2001, Leadership Competencies, Canada: Publihed Hertage Branch.

[16] Tina Afiatin, 2009, Pembelajaran Berbasis Student Centered Learning. Tersedia pada http://www. inparametric.com.

[17] Ali, 1994, Penelitian Pendidikan Prosedur dan Strategi. Bandung: Angkasa

[18] Suharsimi, 1989, Prosedur Penelitian, Jakarta: Rineka Cipta.

[19] Suryabrata , 1989, Metodologi Penelitian, Jakarta: CV Rajawali. 